\title{
Regulation of Gene Expression and Cellular Localization of Cloned Klebsiella aerogenes (K. pneumoniae) Urease
}

\author{
By SCOTT B. MULROONEY, ${ }^{1}$ H. STUART PANKRATZ ${ }^{2}$ \\ AND ROBERT P. HAUSINGER ${ }^{1,2 *}$ \\ Departments of Biochemistry ${ }^{1}$ and Microbiology ${ }^{2}$, Michigan State University, \\ East Lansing, MI 48824, USA
}

(Received 28 December 1988; revised 9 February 1989; accepted 17 February 1989)

\begin{abstract}
The genes for Klebsiella aerogenes ( $K$. pneumoniae) urease were cloned and the protein was overexpressed (up to $18 \%$ of total protein consisted of this enzyme) in several hosts. The small size of the DNA encoding urease $(3.5 \mathrm{~kb})$, the restriction map, and the regulation of enzyme expression directed by the recombinant plasmid are distinct from other cloned ureases. Nickel concentration did not affect urease gene expression, as demonstrated by the high levels of apoenzyme measured in cells grown in nickel-free media. However, nickel was required for urease activity. The overproducing recombinant strain was used for immunogold electron microscopic localization studies to demonstrate that urease is a cytoplasmic enzyme.
\end{abstract}

\section{INTRODUCTION}

Nickel-containing ureases (EC 3.5.1.5), which hydrolyse urea to ammonia and carbon dioxide, play an important role in nitrogen metabolism of plants and micro-organisms (Hausinger, 1987). One of the best-studied bacterial ureases is that from Klebsiella aerogenes [currently Klebsiella pneumoniae (Ørskov, 1974)]; its regulation has been characterized (Friedrich \& Magasanik, 1977; Magasanik, 1982) and the three-subunit enzyme has been purified and shown to contain four nickel ions per native molecule (Todd \& Hausinger, 1987). Our efforts are geared toward elucidating the structure and function of the $K$. aerogenes urease nickel centre by using chemical, biophysical and spectroscopic approaches which require large amounts of enzyme. Typical yields of urease are only $0.1 \mathrm{mg}$ per litre of culture. Therefore, we sought to clone the $K$. aerogenes urease genes and to define conditions needed to optimize enzyme overexpression. In addition, the effect of nickel concentration on urease activity and expression was characterized and the cellular location of recombinant urease was defined.

\section{METHODS}

Gene cloning. K. aerogenes CG253 was obtained from Boris Magasanik and Alex Ninfa (Massachusetts Institute of Technology). Chromosomal DNA of K. aerogenes was isolated (Miller, 1972) and partially digested with Sau3A to yield fragments approximately $40 \mathrm{kbp}$ in size. After phenol extraction and ethanol precipitation, the digestion mixture was ligated to BamHI-cleaved, phosphatase-treated, cosmid vector pWH4 (Herrera et al., 1984) and the resulting DNA was packaged into $\lambda$ phage by using an in vitro packaging system (Boehringer Mannheim) according to the manufacturer's instructions. The phages were used to transfect Escherichia coli strain VCS257 (Stratagene) and kanamycin-resistant $\left(50 \mu \mathrm{g} \mathrm{ml}^{-1}\right)$ colonies were screened on urease indicator plates, which consisted of ammonia-free M9 minimal agar (Maniatis et al., 1982) adjusted to $\mathrm{pH} 6.8$ and supplemented with $10 \%$ (v/v) LB medium, 20 mM-urea, $20 \mu \mathrm{g}$ phenol red $\mathrm{ml}^{-1}$ and $1 \mathrm{ml}$ trace mineral solution $\mathrm{l}^{-1}$ (Smith et al., 1980). One of 102 colonies tested positive, as shown by the development of a red halo after $24 \mathrm{~h}$. The cosmid which encoded urease (designated pKAU1) was isolated (Kado \& Liu, 1981) and transformed into E. coli DH1 (Hanahan, 1983); this plasmid conferred both kanamycin-resistance and urease-positive phenotypes. Purified cosmid pKAU1 was digested with BamHI, and the fragments were ligated into BamHI-cleaved vector pBR328 (Soberon et al., 1980). 
One ampicillin-resistant, tetracycline-sensitive transformant was positive on urease indicator plates, and was found to contain a $10 \mathrm{~kb}$ insert in a plasmid derivative of pBR328 which was termed pKAU2687. Restriction fragments of the $K$. aerogenes insert in pKAU2687 were isolated (Dretzen et al., 1981), subcloned into vector pUC8 (Vieira \& Messing, 1982), transformed into E. coli JM101 (Messing et al., 1981) or JM107 (Yanisch-Perron et al., 1985), and screened on urease indicator plates.

Assays. Culture samples of cells grown in various media $(0.5 \mathrm{ml})$ were centrifuged for $2 \mathrm{~min}$ in an Eppendorf centrifuge at $4{ }^{\circ} \mathrm{C}$, washed twice with $10 \mathrm{~mm}$-potassium phosphate, $1 \mathrm{mM}$-EDTA, $1 \mathrm{~mm}$-2-mercaptoethanol buffer (pH 7.5), and resuspended in the same buffer plus $0.5 \mathrm{~mm}$-phenylmethanesulphonyl fluoride. Cells were disrupted with a Fisher Sonic Dismembranator (micro probe) using three $20 \mathrm{~s}$ bursts at $30 \%$ power. Crude cell extracts were then centrifuged for $15 \mathrm{~min}$ and the supernatant solutions were assayed for urease activity by converting released ammonia to indophenol, which was quantified spectrophotometrically (Todd \& Hausinger, 1987). Protein was assayed by the Lowry method, with bovine serum albumin as the standard.

Nickel-dependence studies. The effect of nickel concentration on the expression of recombinant urease protein and enzyme activity was determined by growing cultures to late exponential phase in ammonia-free MOPS minimal medium (Neidhardt et al., 1974) containing defined nickel levels. Glutamine (10 mM) was used as the sole nitrogen source in order to derepress urease (see below); however, under these conditions urease activity was not required for microbial growth.

Immunological methods. Antibodies that recognized urease were generated in a New Zealand rabbit after injection with homogeneous enzyme, and the IgG fraction was purified from serum (McKinney \& Parkinson, 1987). For immunoblot analyses, samples were denatured, electrophoresed on an SDS 10-15\% acrylamide gradient gel (Laemmli, 1970), and blotted onto nitrocellulose. The blot was probed with anti-K. aerogenes urease antibodies and developed by using anti-rabbit IgG-alkaline phosphatase conjugates (Blake et al., 1984).

Immunogold electron microscopy. Wild-type $K$. aerogenes and $K$. aerogenes(pKAU19) (see below) were grown to stationary phase in ammonia-free MOPS medium supplemented with $10 \mathrm{mM}$-arginine plus $100 \mu \mathrm{M}-\mathrm{NiCl}_{2}$. After centrifugation, the cells were washed once in 10-mM-potassium phosphate, $1 \mathrm{mM}$-EDTA (pH 7), and fixed in 0.1 Mpotassium phosphate $(\mathrm{pH} \mathrm{7.2)}$ containing $1 \%(\mathrm{v} / \mathrm{v})$ glutaraldehyde for 30-60 min at room temperature. The fixed cells were resuspended in $1 \%(\mathrm{w} / \mathrm{v})$ Nobel agar, dehydrated in ethanol, and embedded in Lowicryl K4M (Armbruster et al., 1982). Polymerization was carried out for $2 \mathrm{~d}$ at room or cold-room temperatures under UV irradiation. Thin sections were cut by using an LKB Ultratome III microtome, and placed on Butvar B-98-coated nickel grids. Sections were floated first on a drop of TBST (Tris-buffered saline, pH 7.4, with $0.05 \%$ Tween 20 ) for $5 \mathrm{~min}$ and transferred to $1 \%(\mathrm{w} / \mathrm{v})$ bovine serum albumin in TBST for $15 \mathrm{~min}$ in order to block non-specific sites. The samples were transferred to the anti-urease $\operatorname{IgG}\left(35 \mu \mathrm{g} \mathrm{ml}^{-1}\right)$ in TBST for $1 \mathrm{~h}$, washed three times for 5-15 min each in TBST, and floated on gold particles that were attached to anti-rabbit IgG (15 nm, Jansen) for $1 \mathrm{~h}$ (Bendayan, 1984). After washing in TBST and $\mathrm{H}_{2} \mathrm{O}$, the samples were stained with uranyl acetate and lead citrate. Sections were observed with a Philips CM-10 electron microscope.

\section{RESULTS AND DISCUSSION}

\section{Gene cloning}

The $K$. aerogenes urease genes were localized to a $10 \mathrm{kbp}$ DNA fragment which possesses the restriction map shown in Fig. 1. This region included two BamHI fragments of 7.0 and $3.0 \mathrm{kbp}$, indicating that incomplete digestion had occurred in the subcloning of pKAU2687. When cloned individually, neither fragment conferred urease activity, indicating that sequences spanning the internal BamHI site are required. A PvuII fragment $(6.2 \mathrm{kbp})$ overlapped this BamHI site, yet no urease activity was detected in transformants containing this subcloned fragment (pKAU13). Partial Sau3A digestion of pKAU15 was used to generate clones containing $5.7 \mathrm{kbp}$ (pKAU17) and $3.5 \mathrm{kbp}$ (pKAU23) fragments, both of which conferred urease activity. The $3.5 \mathrm{kbp}$ insert is the smallest reported fragment from any micro-organism which is sufficient to encode active urease.

Urease genes have been cloned from Bacillus pasteurii (Kim \& Spizizen, 1985), a ureasepositive E. coli (Collins \& Falkow, 1988), Proteus mirabilis (Jones \& Mobley, 1988; Walz et al., 1988), and Providencia stuartii (Mobley et al., 1986; Mulrooney et al., 1988). The restriction maps of these clones all differ significantly from that of the $K$. aerogenes urease gene fragment. Klebsiella pneumoniae urease genes also have been cloned by Gerlach et al. (1988); however, the mechanism of gene regulation and properties of the recombinant enzyme were not studied. The restriction pattern, and the associated polypeptide sizes for the $K$. pneumoniae urease genes studied by Gerlach et al. (1988) differ from that of the $K$. aerogenes DNA cloned in the present study. 


$\begin{array}{ll}\begin{array}{l}\text { pUC8 } \\ \text { derived }\end{array} & \begin{array}{l}\text { pBR328 } \\ \text { derived }\end{array} \\ \text { pKAU15 } & \text { pKAU2687 } \\ - & \text { pKAU11 } \\ - & \text { pKAU12 } \\ - & \text { pKAU13 } \\ \text { pKAU17 } & \text { pKAU19 } \\ \text { pKAU23 } & - \\ \end{array}$

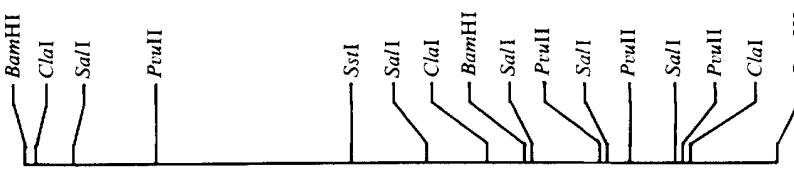

Urease activity

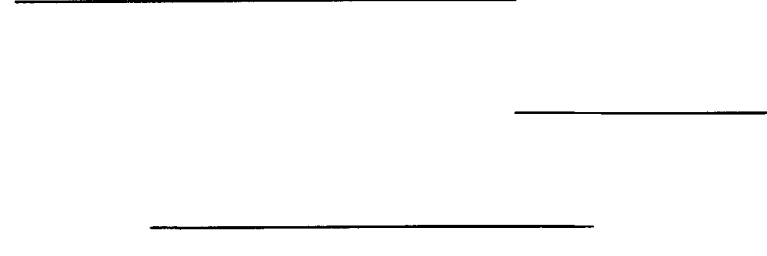


Table 1. Levels of urease activity in strains containing the cloned urease genes of $K$. aerogenes

\begin{tabular}{|c|c|c|c|c|}
\hline \multirow[b]{2}{*}{$\begin{array}{l}\text { Time of harvest* } \\
\text { and } \\
\text { culture medium }{ }^{*}\end{array}$} & \multicolumn{4}{|c|}{ Culture specific activity $\left[\mu \mathrm{mol}\right.$ urea $\left.\min ^{-1}(\mathrm{mg} \text { protein })^{-1}\right]$} \\
\hline & $\begin{array}{l}K \text {. aerogenes } \\
\text { wild-type }\end{array}$ & $\begin{array}{l}\text { K. aerogenes } \\
\text { (pKAU19) }\end{array}$ & $\begin{array}{l}\text { S. typhimurium } \\
\text { (pKAU19) }\end{array}$ & $\begin{array}{r}E . \text { coli } \\
\text { (pKAU19 }\end{array}$ \\
\hline \multicolumn{5}{|c|}{ Exponential growth phase } \\
\hline LB & $0 \cdot 0$ & $6 \cdot 1$ & $2 \cdot 5$ & $1 \cdot 4$ \\
\hline $\mathrm{MOPS}+\mathrm{CA}+\mathrm{N}$ & $0 \cdot 1$ & $6 \cdot 4$ & $11 \cdot 2$ & $9 \cdot 1$ \\
\hline MOPS + N & $0 \cdot 3$ & 49 & 111 & 107 \\
\hline MOPS + Gln & $0 \cdot 4$ & 34 & $48 \cdot 3$ & 109 \\
\hline MOPS + Arg & $3 \cdot 3$ & 122 & $29 \cdot 5$ & 165 \\
\hline \multicolumn{5}{|c|}{ Stationary growth phase } \\
\hline MOPS + Gln & $1 \cdot 1$ & 263 & 219 & 119 \\
\hline MOPS + Arg & 1.7 & 240 & 403 & 176 \\
\hline
\end{tabular}

* Exponential phase cultures were harvested at $\mathrm{OD}_{600}=1$.

$\uparrow$ The media were either LB (Luria-Bertani medium; Maniatis et al., 1982) or MOPS minimal medium (Neidhardt $e t$ al., 1974). For the latter, the nitrogen source was altered to include $0.5 \%$ Casamino acids (CA), $10 \mathrm{~mm}-\mathrm{NH}_{4} \mathrm{Cl}(\mathrm{N}), 10 \mathrm{mM}$-glutamine $(\mathrm{Gln})$ or $10 \mathrm{~mm}$-arginine (Arg). All cultures contained $100 \mu \mathrm{M}-\mathrm{NiSO}_{4}$ and plasmid-bearing cultures contained $30 \mu \mathrm{g}$ chloramphenicol $\mathrm{ml}^{-1}$.

Urease activity in E. coli JM107(pKAU23) was only $1 \%$ of that observed for pKAU19; nevertheless the same pattern of regulation was demonstrated. In addition, immunoblot analysis of this clone demonstrated that all three urease polypeptides were present at levels consistent with the activity (data not shown), i.e. the reduced activity of the $3.5 \mathrm{kbp}$ clone is not due to production of low-activity protein. The larger DNA fragment may possess ancillary genes which enhance the levels of urease expression. In this regard, minicell analysis has demonstrated the presence of multiple, non-urease genes in the urease operon of other species (Gerlach et al., 1988; Jones \& Mobley, 1988; Mulrooney et al., 1988; Walz et al., 1988).

\section{Characterization of the urease made by strains containing pKAU19}

Crude cell extracts of E. coli DH1(pKAU19) and S. typhimurium(pKAU19) were examined by using immunoblot analysis (Fig. 2). Three urease subunits of the expected size were shown to be expressed in each case. These results demonstrate that urease-processing or nickel-insertion activities, if required, are encoded either on the $5.7 \mathrm{kbp}$ pKAU19 fragment or in the heterologous hosts. Furthermore, enzyme purified from $K$. aerogenes(pKAU19) was demonstrated to be identical to wild-type enzyme in subunit composition, nickel content, specific activity, and inhibitor sensitivity (data not shown). Routine purification of urease is now carried out from stationary-phase cultures of $K$. aerogenes(pKAU19), resulting in 100- to 200 -fold increases in yield over wild-type levels.

\section{Effects of nickel concentration on urease gene expression and urease activity}

Derepressed, stationary-phase $K$. aerogenes(pKAU19) cultures grown in media of different nickel concentrations yielded identical intensities of anti-urease antibody cross-reactive material (Fig. 3). Hence, nickel does not affect expression of urease in strains with this plasmid. The urease activities, however, were greatly affected by nickel concentration, and 100-200 $\mu \mathrm{M}-$ nickel was required for maximum activity (Fig. 3). The high requirement may reflect the ability of medium components to bind nickel. The production of inactive urease apoenzyme by this enteric bacterium is similar to the case of soybean, where apoenzyme was shown to be synthesized in the absence of nickel (Winkler et al., 1983). Furthermore, the algae Phaeodactylum tricornutum and Tetraselmis subcordiformis (Rees \& Bekheet, 1982), the cyanobacterium Anabaena cylindrica (Mackerras \& Smith, 1986), and the purple sulphur bacterium Thiocapsa roseopersicina (Bast, 1988) have also been suggested to synthesize urease apoenzyme in the absence of nickel. The microbial studies were based on reconstitution of urease activity for cells grown under nickel-free conditions when nickel was added, even in the 


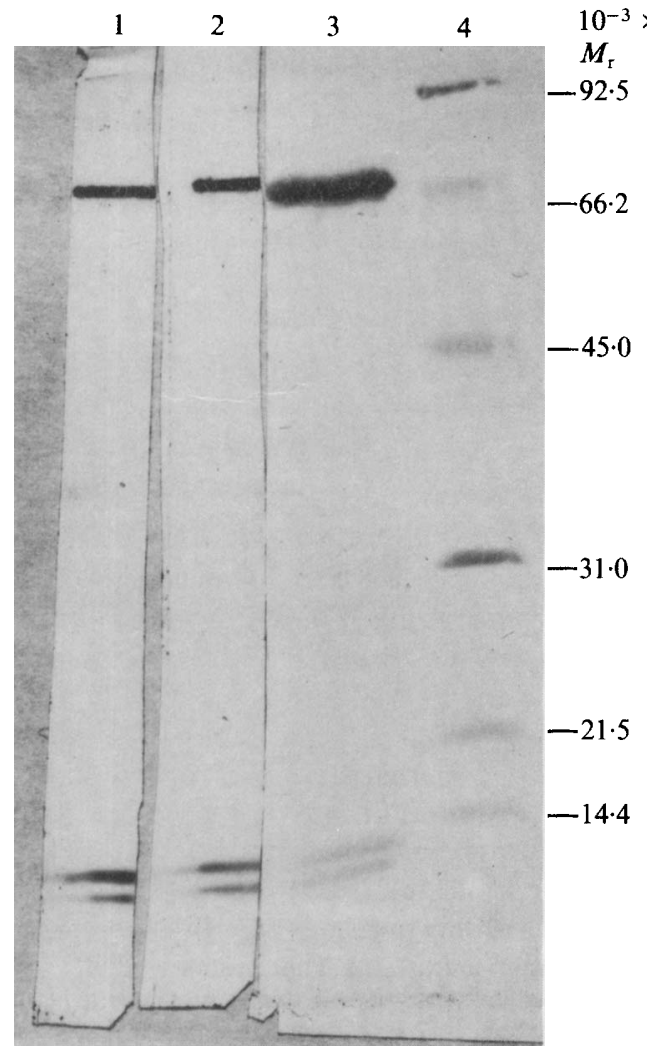

Fig. 2
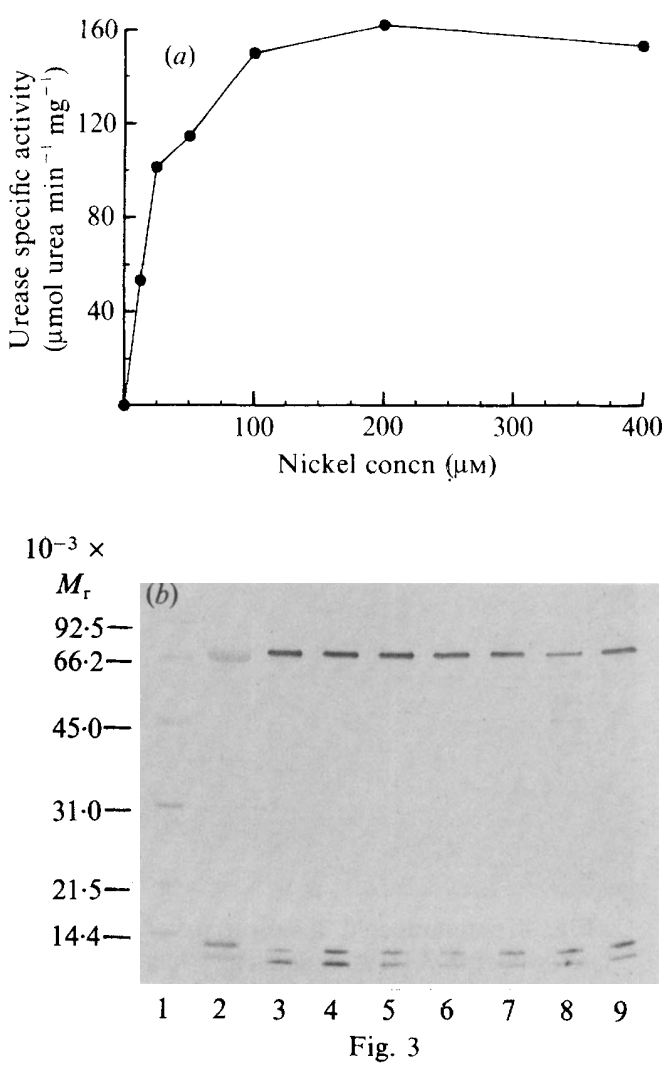

Fig. 2. Immunoblot analysis of recombinant urease expressed in E. coli DH1 and S. typhimurium. Samples of crude extracts of $E$. coli DH1(pKAU19) (lane 1) and S. typhimurium(pKAU19) (lane 2) containing $0 \cdot 1$ units $(50 \mathrm{ng}$ ) of urease were analysed. A standard of purified $K$. aerogenes urease (lane 3 ) and $M_{\mathrm{r}}$ standards (lane 4) were also run and stained for total protein with Amido black. The migration position for $\boldsymbol{M}_{\mathrm{r}}$ markers (phosphorylase $b$, bovine serum albumin, ovalbumin, carbonic anhydrase, soybean trypsin inhibitor, lysozyme; Bio-Rad) are indicated to the right of the figure.

Fig. 3. Effect of nickel concentration on recombinant urease expression and activity. (a) Urease specific activity was determined for $K$. aerogenes(pKAU19) after growth in media containing the indicated nickel concentrations. (b) The level of urease protein expression was quantified for each sample by immunoblot staining. Lanes 1 and 2 are Amido-black-stained $M_{\mathrm{r}}$ standards amd purified urease, respectively. Lanes $3-9$ represent the samples ( $2 \mu \mathrm{g}$ protein) obtained from cultures containing $0,12 \cdot 5,25,50,100,200$, and $400 \mu \mathrm{M}$-nickel, respectively.

presence of protein-synthesis inhibitors. In contrast to the lack of nickel-dependent regulation of ureases, nickel-containing hydrogenases from Bradyrhizobium japonicum and Alcaligenes latus have been shown to exhibit nickel-dependent expression (Stults et al., 1986; Doyle \& Arp, 1988).

\section{Immunogold localization}

The urease in cells of $K$. aerogenes containing pKAU19 is a cytoplasmic enzyme as shown by immunogold electron microscopy localization (Fig. 4). This result is consistent with the observed enzyme behaviour during purification. Urease from wild-type $K$. aerogenes behaved identically to recombinant enzyme during isolation, which is consistent with the reported cytoplasmic location from cell fractionation studies (Friedrich \& Magasanik, 1977). Wild-type cells which contain 1-5 $\mu \mathrm{M}$-urease (calculated as in Kellenberger et al., 1987), were insufficiently labelled by the immunogold technique to allow localization, as expected from the findings of Kellenberger et al. (1987), who state that a cytoplasmic protein cannot be detected by this method at concentrations less than $10-100 \mu \mathrm{M}$. 

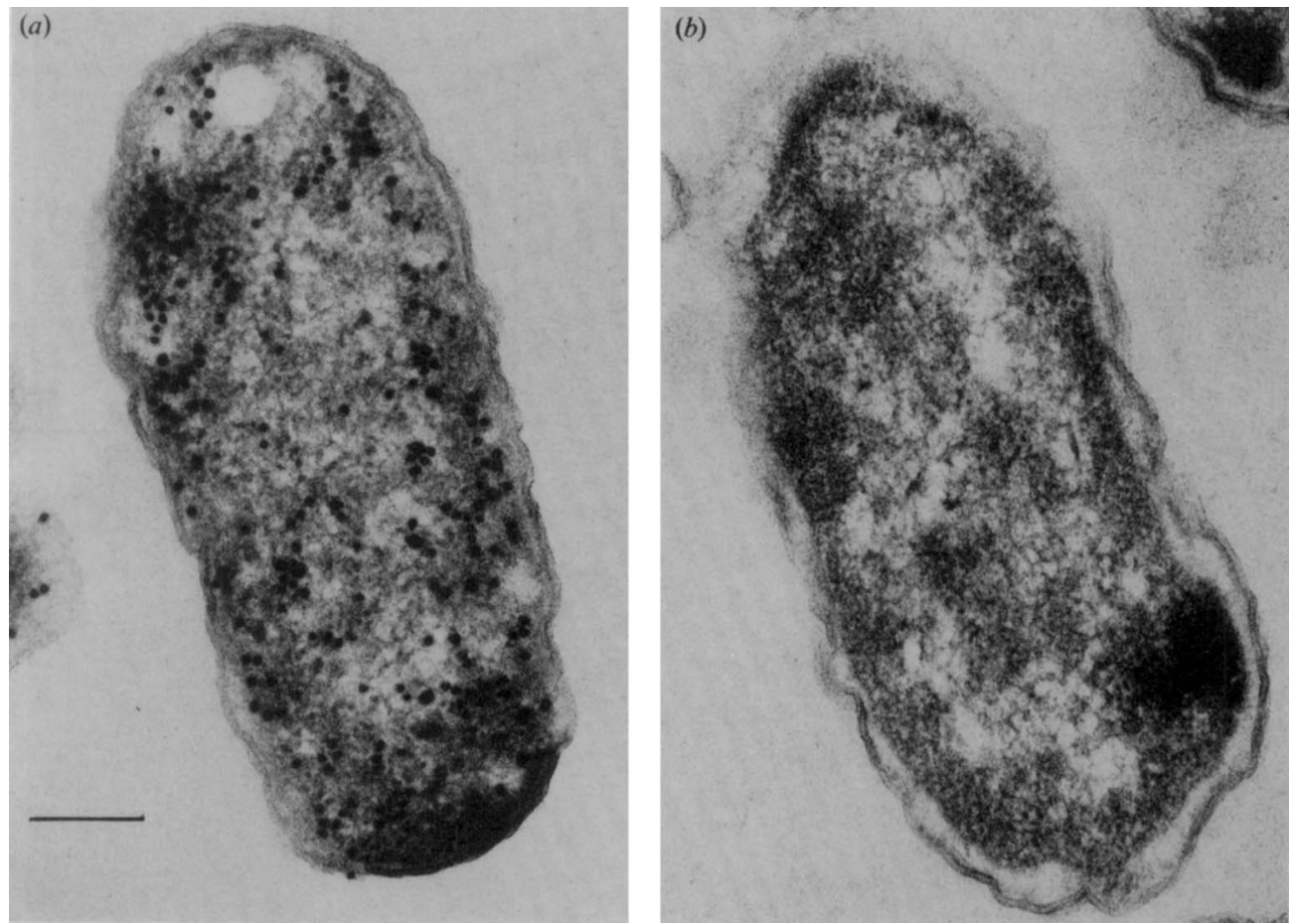

Fig. 4. Immunogold localization of recombinant $K$. aerogenes urease. (a) Thin sections of $K$. aerogenes(pKAU19) expressing recombinant urease $\left(247 \mu\right.$ mol urea hydrolysed $\left.\mathrm{min}^{-1} \mathrm{mg}^{-1}\right)$ were reacted with anti-urease antibodies and labelled with anti-rabbit IgG-gold particles. Urease was localized to the cytoplasmic portion of the cell. (b) Similar experiments were carried out with wild-type $K$. aerogenes $\left(2.0 \mu \mathrm{mol}\right.$ urea hydrolysed $\left.\mathrm{min}^{-1} \mathrm{mg}^{-1}\right)$. Bar, $0 \cdot 2 \mu \mathrm{m}$.

Our results contrast with two previous electron microscopic localization studies involving urease from a Staphylococcus species (McLean et al., 1985) and from Proteus mirabilis (McLean et al., 1986). The earlier workers utilized tetraphenylboron, a compound which reacts with ammonia to form a precipitate; ammonia was exchanged for electron-dense silver ions to allow visualization by electron microscopy after thin sectioning. The precipitated metal was observed on the membrane of the Gram-positive Staphylococcus sp. (McLean et al., 1985) or in the periplasmic space and on the outer membrane of the Gram-negative P. mirabilis (McLean et al., 1986). The discrepancy between these earlier studies and our findings may be due to the inability of tetraphenylboron to cross the cytoplasmic membrane, thus it could only react with external ammonia.

Note added in proof: recent analyses of $E$. coli(pKAU23) have not exhibited any urease activity, in contrast to the low levels described above. Thus, the $3.5 \mathrm{kbp}$ DNA fragment may not contain all of the $K$. aerogenes urease genes.

We thank H. Mobley for comments on the manuscript, and A. Ninfa and B. Magasanik for providing the $K$. aerogenes strain used in this study. We thank C. Kao and L. Snyder for helpful suggestions on recombinant techniques, and M. Todd for purification and characterization of urease from $K$. aerogenes(pKAU19). This work was supported by the Michigan State University Agricultural Experiment Station (article no. 12667) and by Public Health Service Grant AI 22387 to R.P.H. from the National Institutes of Health.

\section{REFERENCES}

Armbruster, B. L., Carlemalm, E., Chiovetti, R., Garavito, R. M., Новot, J. A., Kellenberger, E. \& VILLIGER, W. (1982). Specimen preparation for electron microscopy using low temperature embedding resins. Journal de Microscopie 126, 77-85.

BAST, E. (1988). Nickel requirement for the formation of active urease in purple sulphur bacteria (Chromatiaceae). Archives of Microbiology 150, 6-10.

Bendayan, M. (1984). Protein A-gold electron microscopic immunochemistry: methods, applications, 
and limitations. Journal of Electron Microscopy Technique 1, 243-270.

Blake, M. S., Johnston, K. H., Russell-Jones, G. L. \& GotsChLICH, E. C. (1984). A rapid, sensitive method for detection of alkaline phosphataseconjugated anti-antibody on western blots. Analytical Biochemistry 136, 175-179.

Collins, C. M. \& Falkow, S. (1988). Genetic analysis of an Escherichia coli urease locus: evidence of DNA rearrangement. Journal of Bacteriology 170, 10411045.

Doyle, C. M. \& ARP, D. J. (1988). Nickel affects expression of the nickel-containing hydrogenase of Alcaligenes latus. Journal of Bacteriology 170, 38913896.

Dretzen, G., Bellard, P., Sassone-Corsi, P. \& Chambon, P. (1981). A reliable method for recovery of DNA fragments from agarose and acrylamide gels. Analytical Biochemistry 112, 295-298.

FRIEDRICH, B. \& MAGASANIK, B. (1977). Urease of Klebsiella aerogenes: control of its synthesis by glutamine synthetase. Journal of Bacteriology 131, 446-452.

Gerlach, G.-F., ClegG, S. \& Nichols, W. A. (1988). Characterization of the genes encoding urease activity of Klebsiella pneumoniae. FEMS Microbiology Letters 50, 131-135.

HANAHAN, D. (1983). Studies on transformation of Escherichia coli with plasmids. Journal of Molecular Biology 166, 557-580.

Hausinger, R. P. (1987). Nickel utilization by microorganisms. Microbiological Reviews 51, 22-42.

Herrera, A., Elhai, J., Hohn, B. \& Wolk, C. P. (1984). Infrequent cleavage of cloned Anabaena variabilis DNA by restriction endonucleases from $A$. variabilis. Journal of Bacteriology 160, 781-785.

Jones, B. D. \& Mobley, H. L. T. (1988). Proteus mirabilis urease: genetic organization, regulation, and expression of structural genes. Journal of Bacteriology 170, 3342-3349.

KADO, C. I. \& LIU, S.-T. (1981). Rapid procedure for detection and isolation of large and small plasmids. Journal of Bacteriology 145, 1365-1373.

Kellenberger, E., DURRENBERger, M., Villiger, W., Carlemalm, E. \& Wurtz, M. (1987). The efficiency of immunolabel on Lowicryl sections compared to theoretical predictions. Journal of Histochemistry and Cytochemistry 35, 959-969.

KIM, S.-D. \& SPIZIZEN, J. (1985). Molecular cloning and expression of Bacillus pasteurii urease gene in Escherichia coli. Korean Journal of Applied Microbiology \& Bioengineering 13, 297-302.

LAEMMLI, U. K. (1970). Cleavage of structural proteins during the assembly of the head of bacteriophage $\mathrm{T} 4$. Nature, London 227, 680-685.

MackerRas, A. H. \& Smith, G. D. (1986). Urease activity of the cyanobacterium Anabaena cylindrica. Journal of General Microbiology 132, 2749-2752.

Maclachlan, P. R. \& SANderson, K. E. (1985). Transformation of Salmonella typhimurium with plasmid DNA: differences between rough and smooth strains. Journal of Bacteriology 161, 442-445.

MagasaniK, B. (1982). Genetic control of nitrogen assimilation in bacteria. Annual Review of Genetics 16, 135-168.

Maniatis, T., Fritsch, E. F. \& SAmbrooK, J. (1982).
Molecular Cloning: a Laboratory Manual. Cold Spring Harbor, NY: Cold Spring Harbor Laboratory.

MCKinney, M. M. \& PARKinson, A. (1987). A simple, non-chromatographic procedure to purify immunoglobulins from serum and ascites fluid. Journal of Immunological Methods 96, 271-278.

Mclean, R. J. C., Cheng, K.-J., Gould, W. D. \& COSTERTON, J. W. (1985). Cytochemical localization of urease in a rumen Staphylococcus sp. by electron microscopy. Applied and Environmental Microbiology 49, 253-255.

Mclean, R. J. C., Cheng, K.-J., Gould, W. D., Nickel, J. C. \& Costerton, J. W. (1986). Histochemical and biochemical urease localization in the periplasm and outer membrane of two Proteus mirabilis strains. Canadian Journal of Microbiology 32, 772-778.

Messing, J., Crea, R. \& Seeburg, P. H. (1981). A system for shotgun DNA sequencing. Nucleic Acids Research 9, 309-321.

Miller, J. H. (1972). Experiments in Molecular Genetics. Cold Spring Harbor, NY: Cold Spring Harbor Laboratory.

Mobley, H. L. T., Jones, B. D. \& Jerse, A. E. (1986). Cloning of urease gene sequences from Providencia stuartii. Infection and Immunity 54, 161-169.

Mulrooney, S. B., LynCH, M. J., Mobley, H. L. T. \& Hausinger, R. P. (1988). Purification, characterization, and genetic organization of recombinant Providencia stuartii urease expressed by Escherichia coli. Journal of Bacteriology 170, 2202-2207.

NeidhardT, F. C., BLOCH, P. L. \& SMITH, D. F. (1974). Culture media for enterobacteria. Journal of Bacteriology 119, 736-747.

ØRSKOV, I. (1974). Genus VI. Klebsiella Trevisan 1885. In Bergey's Manual of Determinative Bacteriology, 8th edn, pp. 321-324. Edited by R. E. Buchanan \& N. E. Gibbons. Baltimore: Williams \& Wilkins.

REES, T. A. V. \& BEKHEET, I. A. (1982). The role of nickel in urea assimilation by algae. Planta 156, 385387.

Smith, C. J., Hespell, R. B. \& Bryant, M. P. (1980). Ammonia assimilation and glutamate formation in the anaerobe Selenomonas ruminantium. Journal of Bacteriology 141, 593-602.

Soberon, X., Covarrubias, L. \& Bolivar, F. (1980). Construction and characterization of new cloning vehicles, IV. Deletion derivatives of pBR322 and pBR325. Gene 9, 287-305.

Stults, L. W., Sray, W. A. \& MaIer, R. J. (1986). Regulation of hydrogenase biosynthesis by nickel in Bradyrhizobium japonicum. Archives of Microbiology 146, 280-283.

Todd, M. J. \& Hausinger, R. P. (1987). Purification and characterization of the nickel-containing multicomponent urease from Klebsiella aerogenes. Journal of Biological Chemistry 262, 5963-5967.

Vieira, J. \& MEssing, J. (1982). The pUC plasmids, an M13mp7-derived system for insertion mutagenesis and sequencing with universal primers. Gene 19, 259-268.

Walz, S. E., Wray, S. K., Hull, S. I. \& Hull, R. A. (1988). Multiple proteins encoded within the urease gene complex of Proteus mirabilis. Journal of Bacteriology 170, 1027-1033. 
Winkler, R. G., Polacco, J. C., Eskew, D. L. \& WELCH, R. M. (1983). Nickel is not required for apourease synthesis in soybean seeds. Plant Physiology $72,262-263$.
Yanisch-Perron, C., Vieira, C. \& Messing, J. (1985). Improved M13 phage cloning vectors and host strains: nucleotide sequences of the M13mp18 and pUC19 vectors. Gene 33, 103-119. 